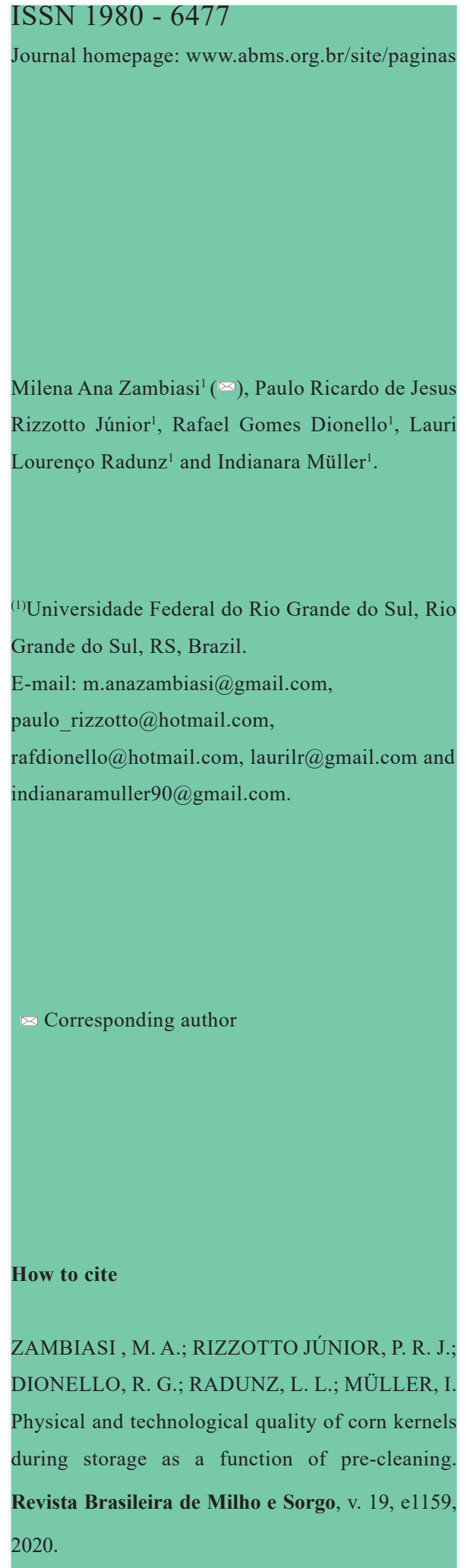

\section{PHYSICAL AND TECHNOLOGICAL QUALITY OF CORN KERNELS DURING STORAGE AS A FUNCTION OF PRE-CLEANING}

\begin{abstract}
Maize is the most cultivated and consumed cereal in Brazil, which is the world's third largest producer of this grain. Estimated losses due to pest attack, especially pest insects and fungi, represent approximately $10 \%$ of the total production. The pre-cleaning phase allows the reduction of foreign matters and impurities (IM) present in the grains, which are used as food and shelter for stored grain pests. The aim of this work was to evaluate the effect of pre-cleaning on the physical and technological quality of corn kernels, during bulk storage in a silodryer. The grains were harvested with a combine harvester, at a moisture content of around $17 \%$ and $0.84 \%$ of IM. Part of the grains was submitted to pre-cleaning and subsequently stored in a silo, while the other part was directly stored in a silo-dryer. After pre-cleaning, the grains were sent to the silo-dryer with $0.12 \%$ of IM. Drying was carried out by blowing natural air through the grain and the process was completed when the grains reached approximately $12 \%$ moisture content. It was concluded that pre-cleaning provided lower hygroscopic equilibrium moisture, reduced the presence of insect damaged grains, and improved the technological classification of grains during storage.
\end{abstract}

Keywords: Quality, Impurities, Moisture content, Technological classification.

\section{QUALIDADE FÍSICAE TECNOLÓGICADE GRÃOS DE MILHO DURANTE O ARMAZENAMENTO EM FUNÇÃO DA PRÉ-LIMPEZA}

\begin{abstract}
Resumo - O milho é o cereal mais cultivado e consumido no Brasil, ocupando a posição de terceiro maior produtor mundial. Estima-se que as perdas pelo ataque de pragas sejam de aproximadamente $10 \%$ do total produzido, principalmente por insetos e fungos. A etapa de pré-limpeza permite a redução do conteúdo de impurezas e matéria estranhas (IM) da massa de grãos, utilizadas como alimento e abrigo para pragas de grãos armazenados. O objetivo com o trabalho foi avaliar o efeito da pré-limpeza na qualidade física e tecnológica de grãos de milho durante o armazenamento em silo-secador. Os grãos foram colhidos com colhedora automotriz com teor de água em torno de $17 \%$ e $0,84 \%$ IM. Parte dos grãos foi encaminhada à pré-limpeza, para posteriormente ser depositada no silo, enquanto a outra parte foi armazenada diretamente em silo secador. Após a prélimpeza, os grãos foram encaminhados para o silo-secador com $0,12 \%$ de IM. A secagem foi realizada com insuflação de ar natural e concluída quando os grãos atingiram aproximadamente o teor de água de $12 \%$. Conclui-se que a pré-limpeza proporcionou menor umidade de equilíbrio higroscópico, reduziu a presença de grãos danificados por insetos e melhorou a classificação tecnológica dos grãos durante o armazenamento.
\end{abstract}

Palavras-chave: Qualidade, Impurezas, Teor de água, Classificação tecnológica. 
Maize (Zea mays L.) is the most cultivated and consumed cereal in Brazil, which is the world's third largest producer of this grain, surpassed by the United States and China. In addition, it is considered one of the most important products of the agricultural sector, not only in Brazil but worldwide (United States Department of Agriculture, 2019). According to Strazzi (2015), maize derivatives are used in over 150 different industrial products and it has been widely studied since it has a high potential for use as an ingredient in the production of various petroleum/chemical products.

Although Brazil is one of the world's largest grain producers, the estimated quantitative losses represent approximately $10 \%$ of the total crop production, caused mainly by insects, rodents and fungi. Quantitative and qualitative losses, mainly due to contaminants in the stages of pre and postharvest of grains in Brazil, have increased food safety risk for humans and animals (Lorini et al., 2015).

Critical factors for fungal postharvest infection and subsequent synthesis of mycotoxins include initial grain moisture content, timeliness of harvest, length of wet holding before drying, the amount of broken corn kernels and foreign materials, the amount of grain dust, the type and quality of storage structures, grain temperature, the interstitial air relative humidity, headspace condensation, bulk grain moisture movement, and insect infestation (Channaiah \& Maier, 2014).

Therefore, pre-cleaning may play an important role in diminishing losses during storage by reducing the content of foreign matter and impurities in the grain mass, which serve as food and shelter for pests of stored products. Also, in this stage, a large part of the broken grains is eliminated, thus making it possible to store whole grains predominantly, which reduces the possibility of occurrence of pests, since there are secondary insect pests that attack only broken grains or even those grains already attacked by primary insect pests which damage whole grains. In addition, these impurities and grain fragments interfere with the porosity, making it difficult to aerate the grain mass, which leads to problems in humidity and temperature control of the stored product (Silva, 2008).

During the storage of grains, there are quantitative and qualitative losses that are gradual, irreversible and cumulative. It is necessary to invest in operations aimed at reducing the loss of quality through post-harvest management. The production of quality grains is prioritized, but this quality must be maintained until the consumption of these grains (Burkot, 2014).

Therefore, the aim of this work was to verify the effect of pre-cleaning on the physical and technological quality of corn kernels, during bulk storage in a masonry silo-dryer.

\section{Material and methods}

The research was conducted at the Experimental Agronomic Station (EEAUFRGS), in the municipality of Eldorado do Sul. 
Maize (Zea mays L.), a Pioneer 30F53VYHR hybrid, was cultivated in the second summer crop of 2017/18, according to the technical indications.

The grains were harvested in the second half of March with a combine harvester, at a moisture content of around $17 \%$ and foreign matter and impurities of $0.84 \%$. After harvest, a portion of the grains was submitted to pre-cleaning, while the other portion did not go through precleaning and was sent directly to the silo dryer. Pre-cleaning was carried out in a grain cleaning machine, produced by Ferrabil, with a capacity for 25 tons/hour, equipped with circular screen sieves, where the superior had a $10 \mathrm{~mm}$ diameter and the inferior 6 and $4 \mathrm{~mm}$. After pre-cleaning, corn kernels were directed to the silo-dryer with $0.12 \%$ of foreign matter and impurities.

Each silo-dryer received about 5 tons of grains and, simultaneously, started the drying process of the pre-cleaned grains and of those without pre-cleaning, through natural air blowing in the periods when the psychrometric conditions were adequate, with the specific flow rate of 1.8 $\mathrm{m}^{3} \min ^{-1} \mathrm{t}^{-1}$, as indicated by Silva (2008). The silo-dryers are built in masonry, with a height of $1.9 \mathrm{~m}$, diameter of $2.10 \mathrm{~m}$ and metal sheet used on the floor, with $20 \%$ of its total area perforated.

The drying process was completed when the grains reached approximately $12 \%$ moisture, which occurred after about ten days of drying. At the end of drying, the initial storage time was considered, since the grains remained in the silo-dryer, subjected to maintenance aeration at intervals of approximately 3 weeks during the 8-month storage period. Mean values of temperature and relative humidity at the experiment site are shown in Figure 1.

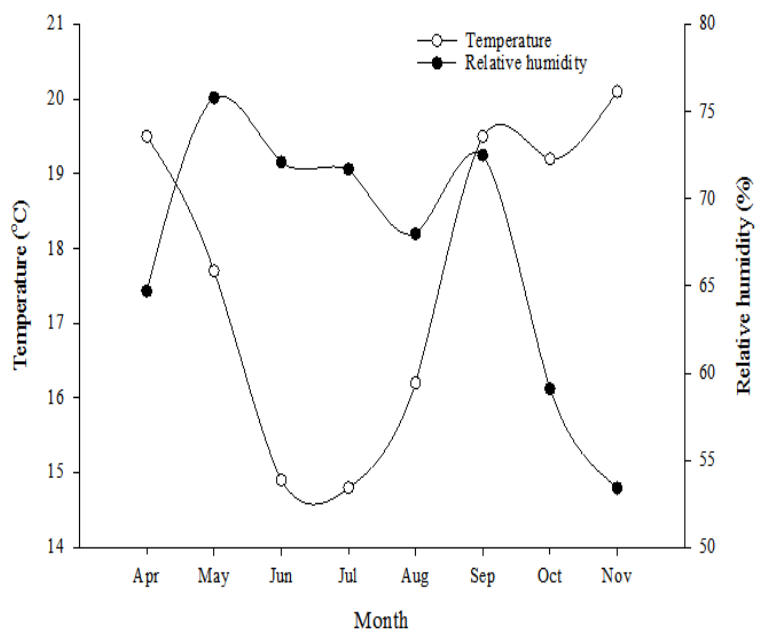

Figure 1. Mean values of temperature and relative humidity of the environment, according to data from the EEA-UFRGS Weather Station, 2017.

For the analysis of grain quality, samples were collected with the use of manual grain probes, as described in NI 60/2011 (Brasil, 2011). These samples were obtained shortly after harvesting (additional treatment), at the start of storage and thereafter at 60-day intervals. Soon after sampling, the samples were sent to the laboratory for analyses of moisture content, bulk density and thousand grain weight, in addition to technological quality to quantity damaged grains, broken grains, foreign matter and impurities, and insect damaged grains.

To obtain the same moisture base, the data 
obtained were adjusted to a moisture content of $13 \%$ according to equation 1.

$$
F W=I W x \frac{(100-I M C)}{(100-F M C)}
$$

Equation 1

Where: $\mathrm{FW}=$ final weight, grains with a moisture content of $13 \%(\mathrm{~g})$;

$\mathrm{IW}=$ initial weight, grains with moisture content of the silo-dryer $(\mathrm{g})$;

$\mathrm{IMC}=$ initial moisture content, grains from silodryer (\%); and

$\mathrm{FMC}=$ final moisture content (considering 13\%).

\section{Quality analysis}

Evaluation of the moisture content was performed in an oven at $105 \pm 3^{\circ} \mathrm{C}$, with forced air circulation for 24 hours (Brasil, 2009).

The bulk density was verified using a hectoliter weight scale (Brasil, 2009), with the results expressed in $\mathrm{kg} \mathrm{m}^{-3}$. The thousand grain weight was determined from eight sub-samples of 100 seeds, multiplying the average value of the sub-samples by 10 (Brasil, 2009). In the technological analysis, the defective grains, broken grains, foreign matter and impurities, and insect damaged grains were quantified, being determined according to the methodology presented in the Normative Instruction No. 60/2011 (Brasil, 2011).

\section{Data analysis}

The experiment was conducted in a completely randomized design (CRD), in a double factorial scheme with additional treatment
$(2 \times 5+1)$, with three replicates. The first factor was corn kernels with and without pre-cleaning. The second factor was storage period $(0,60$, 120,180 and 240 days). In the control treatment, the grains were obtained shortly after harvest, before pre-cleaning and storage in a silo-dryer for drying.

Data were submitted to analysis of variance $(p \leq 0.05)$ and, when significant, submitted to Dunnett and Tukey's tests (qualitative factor) and regression analysis (quantitative factor). The residues presented normal distribution. Models were selected based on the significance of the parameters obtained through " $\mathrm{t}$ " test $(\mathrm{p} \leq 0.05)$, significance of the mathematical model $(p \leq 0.05)$, determination coefficient $\left(r^{2} \geq 0.60\right)$ and biological behavior.

\section{Results and discussion}

Table 1 presents the summary of the analysis of variance for the physical and technological evaluations of corn kernels, with and without pre-cleaning and, subsequently, storage period and additional treatment.

The moisture content varied according to the interaction between pre-cleaning and storage time (Table 1), showing an increase up to approximately 100 days (winter period), with a subsequent decrease (Figure 2A). Storage time only influenced the bulk density (Table 1), showing a reduction of approximately $3.7 \%$, regardless of pre-cleaning handling (Figure 2B). 
Table 1. Summary of the analysis of variance $(p \leq 0.05)$ of the data referring to the physical and technological analysis of corn kernels, Pioneer 30F53VYHR hybrid, with and without pre-cleaning, additional treatment and the subsequent period of storage.

\begin{tabular}{cccccccccc}
\hline \multirow{2}{*}{ Source of variation } & DF & \multicolumn{7}{c}{ p-value } \\
\cline { 3 - 10 } & & MC & BD & TGW & FM & BG & DG & IDG & MG \\
\hline Pre-cleaning (PC) & 1 & 0.354 & 0.084 & $<0.001$ & $<0.001$ & $<0.001$ & 0.005 & $<0.001$ & 0.078 \\
Storage period (SP) & 4 & $<0.001$ & $<0.001$ & 0.873 & 0.960 & 0.202 & $<0.001$ & $<0.001$ & $<0.001$ \\
PC x SP & 4 & 0.022 & 0.205 & 0.801 & 0.774 & 0.742 & 0.017 & $<0.001$ & 0.1647 \\
Additional & 1 & $<0.001$ & $<0.001$ & 0.006 & 0.997 & 0.907 & 0.001 & 0.022 & $<0.001$ \\
\hline CV (\%) & - & 2.13 & 0.69 & 1.99 & 39.5 & 26.5 & 20.1 & 73.9 & 18.9 \\
\hline
\end{tabular}

MC (moisture content), BD (bulk density), TGW (thousand grain weight), FM (foreign matter and impurities), BG (broken grains), DG (defective grains), IDG (insect damaged grains), and MG (moldy grains). Adjusted values for moisture content of $13 \%$.

Pre-cleaned grains had a lower moisture content during the entire storage period (Figure 2A), showing that even though they had a lower percentage value of foreign matters and impurities than allowed by legislation, the reduction of those values leads to a decrease in the moisture content of the grain mass. This result corroborates that found by Morais et al. (2016), who verified that soybean grains that are not submitted to precleaning presented higher moisture content than those submitted to pre-cleaning. According to Bragatto \& Barrella (2001), foreign matter and impurities, when subjected to the same conditions of relative humidity and air temperature, present higher values of equilibrium moisture content than grains, providing the formation of a compact and moist mass that favors the development of microorganisms, thus accelerating the deterioration of the product.

This reduction in moisture content may occurbecause of the removal of bothimpurities and broken grains, since they have higher equilibrium moisture content. According to Mohapatra et al. (2017), stored fungi can cause irreparable damage to the grain as well as to the consumer. Therefore, devising a sustainable strategy to prevent contamination and proliferation of fungi in stored grains is of the utmost importance. It is necessary to control the factors that are responsible for fungi contamination and growth, the most important being the moisture content. Thus, pre-cleaning can contribute to the reduction of fungal infestation, as it provides reduction in the moisture content of stored grains.

Moisture content of grains, during the storage period, varies as a function of the 

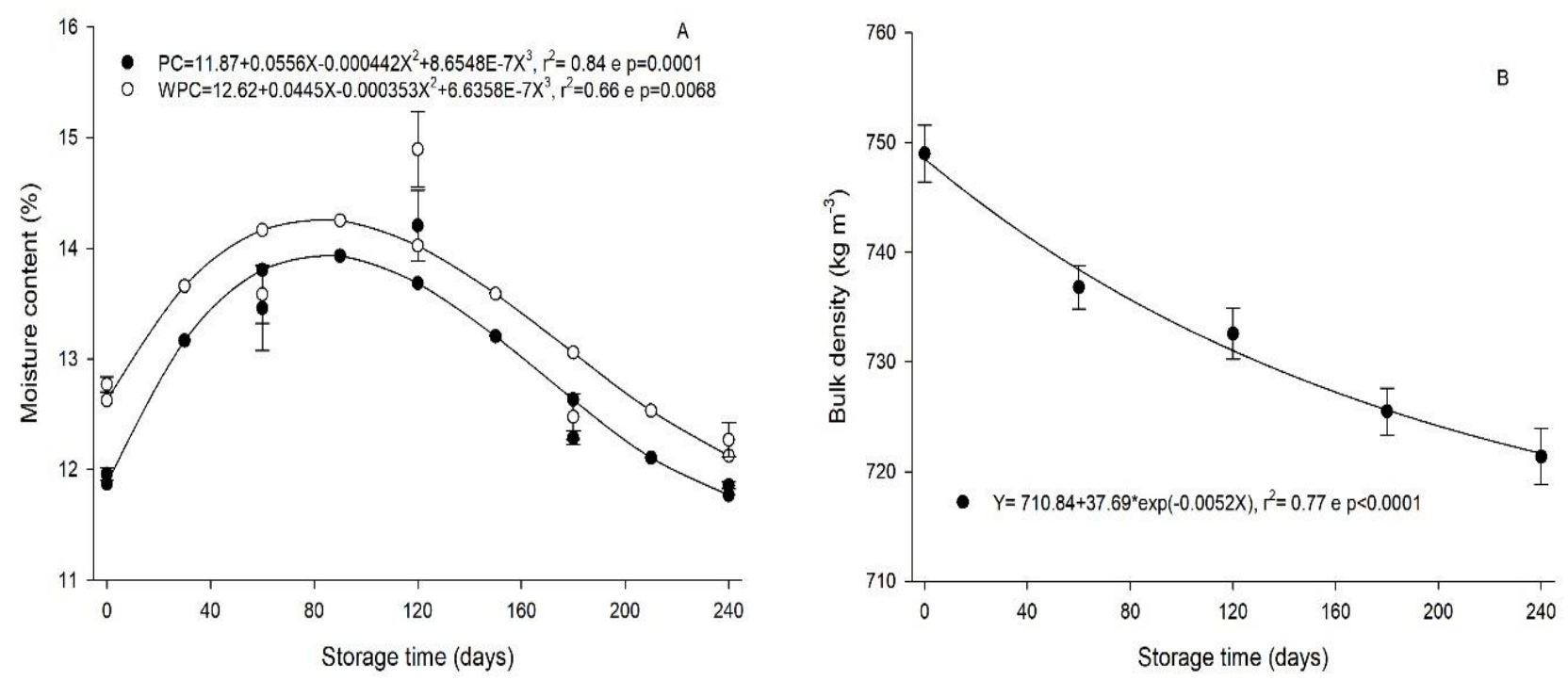

Figure 2. Moisture content (A) and bulk density (B) of corn kernels, Pioneer 30F53VYHR hybrid, with pre-cleaning (PC) and without pre-cleaning (WPC) and subsequent storage time.

grains tending towards hygroscopic balance, changing according to the relative humidity and air temperature, as already verified by other authors when studying corn kernels (Dionello et al., 2000; Schuh et al., 2011; Ferrari Filho et al., 2014; Tiecker Junior et al., 2014; Lima et al., 2016).

Pre-cleaning did not influence the bulk density of grains, only the storage time, which provided a reduction of that value. The results referring to bulk density corroborate those found by Antunes et al. (2011), Tiecker Junior et al. (2014), Ferrari Filho et al. (2014) and Lima et al. (2016), where they observed a decrease in those values for corn kernels during storage. Antunes et al. (2011) attributed this reduction during storage to pest attack and grain respiration, factors that were also responsible for reducing the bulk density of corn kernels in the present study.

Rodrigues et al. (2015) evaluated the bulk density before and after pre-cleaning, where they observed that the reduction of impurities increased the bulk density, a response attributed to the removal of earth and stones. Unlike the results found in the present work, however, besides the percentage of foreign matter and impurities being smaller, only straw remained and broken grains (less than $3 \mathrm{~mm}$ ) were removed from the grain mass.

Reduction of bulk density during storage shows grain deterioration. Besides the loss of dry mass due to grain respiration, storage fungi and pest insects contributed to the reduction of these values. Antunes et al. (2011) and Ferrari Filho et al. (2014) verified that pest insects reduced the specific mass of corn kernels during storage. 
Thousand grain weight before and after pre-cleaning showed a difference, but there was no significant variation over the storage time (Table 1). The average grain weight without precleaning was $338.39 \mathrm{~g}$ and with pre-cleaning $364.21 \mathrm{~g}$, on a dry basis. Pre-cleaning removes foreign materials and impurities, but also removes grains with lower density, thus allowing a higher thousand grain weight after pre-cleaning.

In the technological analysis, the following were identified: damaged grains (rot, moldy, fermented, germinated, insect damaged grains, immature/shriveled grains, and chalky grains), broken grains, foreign matter and impurities, and grained grains. The Normative Instruction (NI) No. 60/2011 describes the maximum values allowed for the classification of corn kernel types (Brazil, 2011).

For the percentage of defective grains and insect damaged grains, there was interaction between the pre-cleaning and storage time factors. For foreign materials/impurities and broken grains, there was a statistical difference only as to pre-cleaning, and for moldy grains, there was a significance only as to storage time (Table 1).

The percentage of defective grains presented an increase as a function of the storage time, in a different way for grains with or without pre-cleaning (Figure 3A), whereas the percentage of moldy grains only increased because of storage time (Figure 3B).

The percentage of defective grains increased exponentially over the storage period for grains with and without pre-cleaning (Figure
3A). However, it was observed that pre-cleaned grains presented a lower increase of defective grains, being approximately $7 \%$ lower, at the end of the storage period, when compared to the grains that were not submitted to pre-cleaning. This shows that the pre-cleaning was efficient to keep the percentage of defective grains below the value obtained without pre-cleaning, throughout the storage time.

The increase in grain defects occurred mainly due to the increment of moldy grains over the storage time (Figure 3B and Table 2). After 120 days of storage, the broken grains were moldy, regardless of pre-cleaning handling. This defect is important because, besides causing loss of grain mass and quality, fungi can produce toxic compounds that can be carcinogenic and cause various problems in the animal production chain and to humans. According to Tibola et al. (2016), cleaning and sorting methods contributed to a reduction in the mycotoxin content of industrial wheat by-products.

The percentage of moldy grains only increased as a function of the storage time, being of around $10 \%$ throughout the 240-day storage period (Table 1 and Figure 3B). Pre-cleaning was not important in fungal growth, probably because there was a low percentage of broken or cracked grains and a low percentage of foreign matter and impurities in the grains after harvest. Mycotoxins are toxic by-products of fungi that contaminate food at all stages of production and during storage. Climate changes increase the risk of human and animal exposure to dietary 

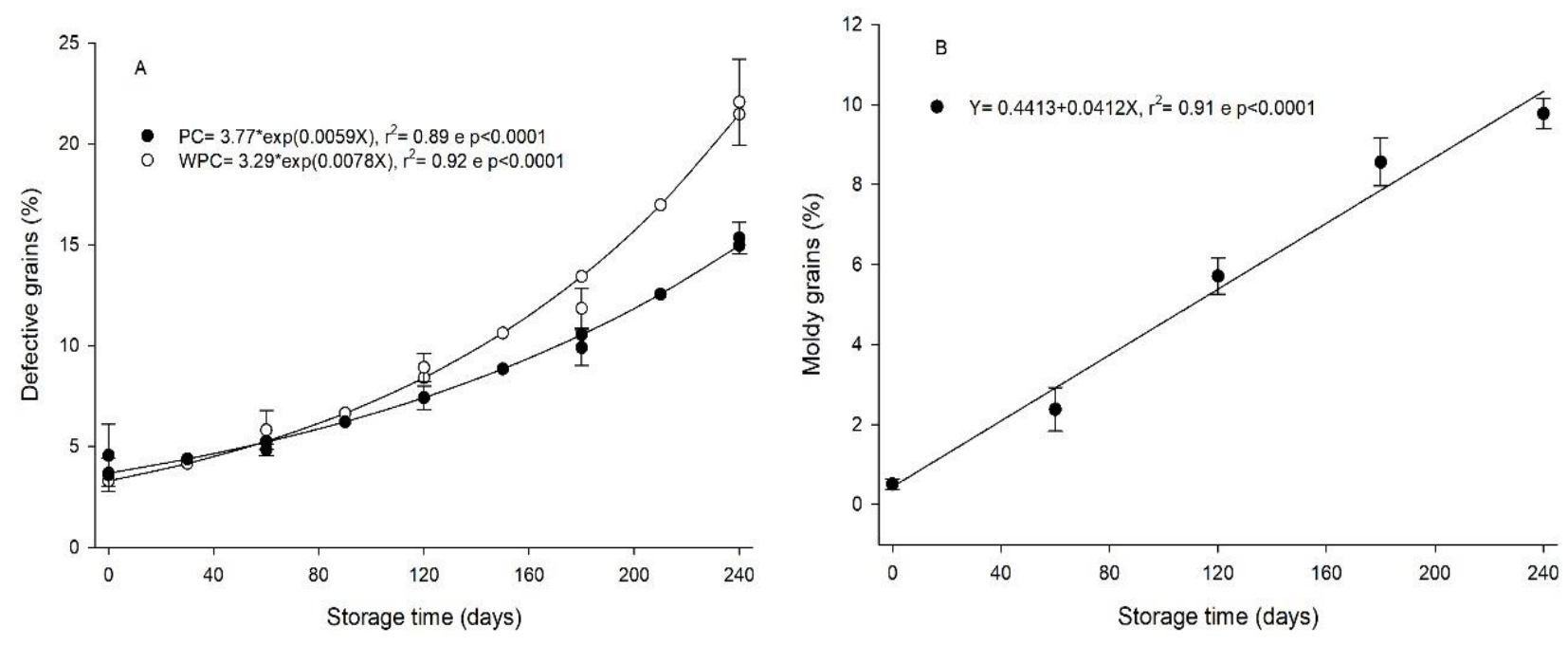

Figure 3. Percentage of defective (A) and moldy (B) corn kernels, Pioneer 30F53VYHR hybrid, with pre-cleaning (PC) and without pre-cleaning (WPC) and subsequent storage time.

mycotoxins in temperate climates. Humans and animals are often exposed to mycotoxins due to contamination of food and feed. Due to the exposure of farm animals (livestock), mycotoxins and their metabolites can be found in milk and meat and their products. So far, over 300 different mycotoxins have been isolated, and only a few are known for their toxic, mutagenic, genotoxic, carcinogenic, and teratogenic potential (Peraica \& Rašić, 2020).

The increase of moldy grains is related to the humidity available for fungus growth. In the winter months, there was an increment in the relative humidity of the air (Figure 1), which generated an increment in grain moisture content. This increase favored the proliferation of fungi in the grain mass, thus increasing the percentage of moldy grains, mainly in broken and cracked grains.
Different conditions of corn kernel storage were also studied by Paraginski et al. (2015), where they observed an increase in the incidence of moldy grains when the grains were stored at $25^{\circ} \mathrm{C}$, compared with storage at 5 and $15^{\circ} \mathrm{C}$. This result can be verified in the present work because, when the temperature was low, in the first months of storage (Figure 1), the number of moldy grains was small, but when the temperature increased, the percentage of moldy grains also increased. The increment in the equilibrium moisture of these grains can also justify this increment in moldy grains in the storage period between 60 and 120 days (Table 2).

During storage, the corn kernels were attacked mainly by Sitophilus zeamais. The percentage of insect damaged grains had an exponential increase (Figure 4), but it was more expressive in grains without pre-cleaning. 


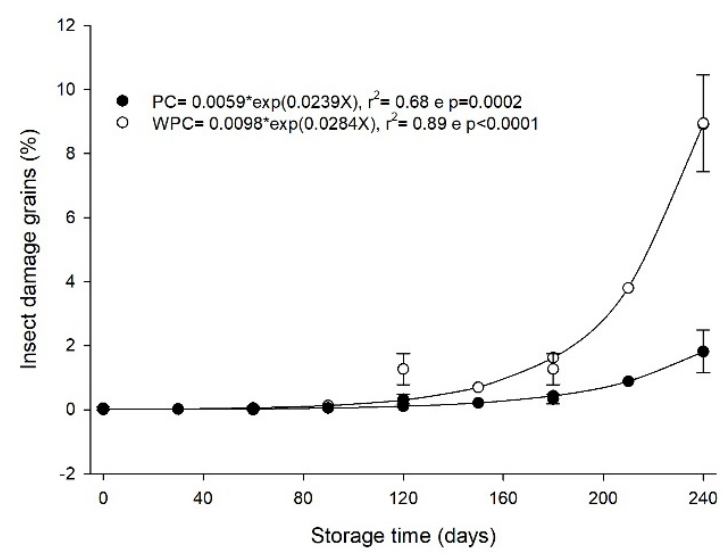

Figure 4. Percentage of insect damaged grains of the Pioneer 30F53VYHR hybrid, with precleaning (PC) and without pre-cleaning (WPC), and subsequent storage.

The presence of insect damaged grains was intensified after 120 days of storage, corresponding to the beginning of August, when the temperature increased (Figure 4). According to Lorini et al. (2015), the temperature increase favors the reproduction and development of insects. Antunes et al. (2011), testing corn kernels infested with $S$. zeamais, observed that, after 60 days of storage, the percentage value of insect damaged grains was $9.77 \%$ and, after 120 days, the percentage was $34.01 \%$. According to the authors, until the sixth month of storage, the grains were still in a condition that was less favorable to insect attack since the temperature was low during that period.

After 240 days of storage, because of a higher insect infestation, the percentage of insect damaged grains increased to approximately $9 \%$ in the grains without pre-cleaning. The grains with pre-cleaning had a lower incidence of insect damaged grains, not exceeding $2 \%$ of damages after the same period, since the removal of impurities may have contributed to the lower development of the insects.

Impurities and foreign material presented a significant variation as to the interaction between storage time and management, showing a lower percentage of this defect in the pre-cleaned grains, which varied from 0.05 to $0.1 \%$ during storage, while the grains without pre-cleaning presented percentage values ranging from 0.53 to $0.63 \%$ (Table 2). This result is similar to those obtained by Rodrigues et al. (2015) in corn kernels.

The percentage of broken grains also showed a significant variation as to the interaction between storage time and management (Table 1), being lower in the pre-cleaned grains, ranging from 0.16 to $0.34 \%$, while in the grains without pre-cleaning, these values varied from 1.91 to $2.55 \%$ (Table 2). Reduction of broken grains and impurities and foreign matter in the pre-cleaned grains can be justified by their removal in the air screen grain cleaner, thus improving the grain typification.

Table 2 shows the comparison of the additional treatment and the treatments with and without pre-cleaning, after drying the grains in a silo-dryer.

The moisture content of grains from the additional treatment was higher when compared to the other treatments, since it was determined before drying, while in the storage treatments, it 
Table 2. Results of the comparison between the additional treatment and the treatments with and without pre-cleaning, after drying of corn kernels in a silo-dryer, obtained through Dunnett's test $(\mathrm{p} \leq 0.05)$ for the physical and technological variables.

Pre

\begin{tabular}{ccccccccc} 
cleaning & $\mathrm{MC}(\%)$ & $\mathrm{BD}\left(\mathrm{kg} . \mathrm{m}^{-3}\right)$ & $\mathrm{TGW}(\mathrm{g})$ & $\mathrm{FM}(\%)$ & $\mathrm{BG}(\%)$ & $\mathrm{DG}(\%)$ & $\mathrm{MG}(\%)$ & $\mathrm{IDG}(\%)$ \\
\hline Without & 12.8 & $747^{*}$ & $336.9 *$ & $0.64^{*}$ & 2.55 & $3.59^{*}$ & $0.56^{*}$ & 0.04 \\
With & 12.3 & $751^{*}$ & 364.6 & 0.15 & 0.34 & $4.55^{*}$ & $0.44^{*}$ & 0.04 \\
Additional & $17.0^{*}$ & $754^{*}$ & $334.5^{*}$ & $0.84^{*}$ & $1.15^{*}$ & $4.59^{*}$ & $0.23 *$ & 0.00
\end{tabular}

Means followed by * do not statistically differ from control treatment according to Dunnet's test $(\mathrm{p} \leq 0,05)$. MC (moisture content), BD (bulk density), TGW (thousand grain weight), FM (foreign matter and impurities), BG (broken grains), DG (defective grains), MG (moldy grains) and IDG (insect damaged grains). Adjusted values for moisture content of $13 \%$.

was determined after grain drying. Table 2 shows that corn kernels were harvested at a moisture content of around $17 \%$ and, after drying, it was reduced to approximately $12 \%$, which is the recommended value for storage (Silva et al., 2008).

The bulk density of grains from the additional treatment and with or without precleaning, at the start of storage, was statistically the same. The bulk density did not present a significant reduction since the drying process at a low temperature did not cause immediate damage to the grain, and drying time did not provide a great reduction of the dry mass due to grain respiration.

The weight of one thousand grains from the treatment without pre-cleaning did not differ from the additional treatment, but the grains submitted to pre-cleaning presented statistically higher values. This may have happened because of the selection, during pre-cleaning, of the larger grains since the very small or light grains can be eliminated together with the impurities and foreign matters in the pre-cleaning process.

Pre-cleaning reduced the values of impurities and foreign matters in the grains to nearly zero, statistically differentiating this from the additional treatment and the grains without pre-cleaning (Table 2). This shows that the use of pre-cleaning was efficient in the removal of foreign matters and impurities.

The percentage of broken grains presented a statistical difference among the grains with and without pre-cleaning and from the additional treatment. Pre-cleaned grains presented a percentage lower than that obtained in the additional treatment, while grains without precleaning had a higher percentage value than those from the additional treatment. Pre-cleaning has contributed to the removal of broken grains, which 
are more susceptible to pest attack, thus helping grain conservation. The highest percentage of broken grains in the lot without pre-cleaning may have occurred because of mechanical damage caused during grain handling.

Both lots of grains, with and without precleaning, at the end of drying, did not increase the percentage of moldy grains in comparison with the additional treatment. Pre-cleaning did not contribute to the removal of moldy grains. Also, drying did not promote the occurrence of moldy grains, showing that the development of fungi during this period was not favored.

The percentage of insect damaged grains did not show a variation after drying for the grains with or without pre-cleaning in relation to the additional treatment, which may have happened because of the lack of such damage soon after harvest.

Corn kernels obtained shortly after harvest (additional treatment) presented values for impurities and/or foreign matter, defective grains, insect damaged grains and broken grains lower than $1,6,2$ and $3 \%$, respectively, being classified as type 1 (Table 3 ).
Grains were classified as type 1 up to 60 days of storage, either with or without precleaning. At 120 days, they were classified as type 2 , mainly due to the increase of moldy grains. At 180 days of storage, only the grains without precleaning showed a reduction in the classification, changing to type 3 . At 240 days of storage, both lots showed a change in the classification, where the pre-cleaned grains were classified as type 3 and the grains without pre-cleaning as out of type.

The highest quality reduction in stored grains without pre-cleaning can be attributed mainly to the increase of insect-damaged and moldy grains since broken grains of less than $3 \mathrm{~mm}$ have not been removed, which are more susceptible to fungal and insect attack.

These results highlight the importance of the pre-cleaning of grains, even when they are harvested with a percentage of impurities and foreign matter lower than that recommended by the Normative Instruction No. 60.

Table 3. Technological classification of corn kernels during storage, according to the Normative Instruction 60 (MAPA, 2011)

\begin{tabular}{cccccc}
\hline \multirow{2}{*}{ Pre-Cleaning } & \multicolumn{5}{c}{ Storage time (days) } \\
\cline { 2 - 5 } & 0 & 60 & 120 & 180 & 240 \\
\hline without & type 1 & type 1 & type 2 & type 3 & out of type \\
with & type 1 & type 1 & type 2 & type 2 & type 3 \\
\hline
\end{tabular}




\section{Conclusions}

Considering the conditions in which the research was carried out, for corn kernels, it can be inferred that:

Reduction of foreign material and/or impurities and broken grains enables lower hygroscopic equilibrium moisture during grain storage;

There is a decrease in the bulk density of grains during storage, regardless of pre-cleaning;

Pre-cleaning minimizes the increase of insect-damaged and defective grains throughout the storage period;

There is an increase of moldy grains during storage, regardless of pre-cleaning; and

The lower the percentage of foreign material and/or impurities, the better the technological classification of the grains during storage.

\section{Acknowledgments}

The authors thank the Postgraduate Program in Phytotechnics of the Federal University of Rio Grande do Sul (UFRGS) and the Coordination for the Improvement of Higher Education Personnel (CAPES), for supporting this study.

\section{References}

ANTUNES, L. E. G.; VIEBRANTZ, P. Grain Chains. USA: John Wiley \& Sons, Inc, C.; GOTTARDI, R.; DIONELlO, R. G. 2014. p. 78-87. Características físico-químicas de grãos de milho atacados por Sitophilus zeamais durante o armazenamento. Revista Brasileira de Engenharia Agrícola e Ambiental, v. 15, n. 6, p. 615-620, 2011. DOI: 10.1590/S141543662011000600012.

BRAGATTO, S. A.; BARRELLA, W. D. Otimização do Sistema de Armazenagem de Grãos: Um estudo de caso. Revista Produção, v. 1, n. 1, 2001.

BRASIL. Ministério da Agricultura, Pecuária e Abastecimento. Padrão oficial de classificação do milho. Instrução Normativa $n^{\circ} 60$, de 22 de dezembro de 2011. Diário Oficial da União, Brasília, DF, 23 dez. 2011. Seção 1, p. 3.

BRASIL. Ministério da Agricultura, Pecuária e Abastecimento. Regras para análise de sementes. Brasília: Mapa/ACS, 2009.

BURKOT, C. R. Aqualidade desejada na secagem e armazenagem de grãos em uma cooperativa no município de Ponta Grossa - PR. 2014. Revista de Gestão e Organizações Cooperativas, v. 1, n. 2, p. 39-50, 2014.

CHANNAIAH, L.; MAIER, D. E. Best stored maize management practices for the prevention of mycotoxin contamination. In: LESLIE, J. F.; LOGRIECO, A. F. Mycotoxin Reduction in$$
\text { . }
$$ 
DIONELLO, R. G.; RADÜNZ, L. L.; CONRAD, de grãos e sementes armazenados. 1. ed. V. J. D.; LUCCA FILHO, O.; ELIAS, M. C. Brasília: Embrapa, 2015.

Temperatura do ar na secagem estacionária e tempo de armazenamento na qualidade de grãos de milho. Revista Brasileira de Agrociência, v. 6, n. 2, p. 137-143, 2000.

FERRARI FILHO, E.; ANTUNES, L. E. G.; TIECKER, A.; DIONELLO, R. G. Controle de gorgulho-do-milho submetido ao tratamento térmico. Revista Brasileira de Milho e Sorgo, v. 10, n. 3, p. 196-204, 2011. DOI: 10.18512/19806477/rbms.v10n3p196-204.

FERRARI FILHO, E.; ANTUNES, L. E. G.; TIECKER, A.; LIMA, R. F.; DIONELLO, R. G. Efeito de diferentes fontes energéticas na secagem e de tempos de armazenagem sobre as características físicas e tecnológicas de grãos de milho. Pesquisa Agropecuária Gaúcha, v. 20, n. 1, p.71-79, 2014.

LIMA, R. F.; TIECKER JUNIOR, A.; RIZZOTO JÚNIOR, P. R. J.; DIONELLO, R. G.; RADÜNZ, L. L. Qualidade de grãos de milho submetidos à secagem com lenha e posteriormente armazenados em ambiente natural. Revista Brasileira de Milho e Sorgo, v. 15, n. 3, p.594606, 11 dez. 2016. DOI: 10.18512/1980-6477/ rbms.v15n3p594-606.

MOHAPATRA, D.; KUMAR, S.; KOTWALIWALE, N.; SINGH, K. K. Critical factors responsible for fungi growth in stored food grains and non-chemical approaches for their control. Industrial Crops and Products, v.108, n. 1, p. 162-182, 2017. DOI: 10.1016/j. indcrop.2017.06.039.

PARAGINSKI, R. T.; ROCKENBACH, B. A.; SANTOS, R. F.; ELIAS, M. C.; OLIVEIRA, M. Qualidade de grãos de milho armazenados em diferentes temperaturas. Revista Brasileira de Engenharia Agrícola e Ambiental, v. 19, n. 4, p. 358-363, 2015. DOI: 10.1590/1807-1929/ agriambi.v19n4p358-363.

PERAICA, M.; RAŠIĆ, D. Risk of exposure to the most important mycotoxins of the genus apergillus for human health. Journal of Plant Protection, vol. 20, n. 3, p. 340-345, 2020.

RODRIGUES, S. I. F. C.; STRINGHINI, J. H; LORINI, I.; KRZYZANOWSKI, F. C.; CECCANTINI, M.; PENZ JÚNIOR, A. M.; FRANÇA-NETO, J. B.; HENNING, A. A.; RIBEIRO,A.M.L.; PERIPOLLI, V.; McNANUS, HENNING, F. A. Manejo Integrado de Pragas C.M. Chemical and energetic content of corn 
before and after pre-cleaning. Ciência Animal TIECKER JUNIOR, GUIMARÃES, L. E.; Brasileira, v. 16, n. 2, p. 158-168, 2015. DOI: FERRARI FILHO, E.; CASTRO, B.; DEL 10.1590/1089-6891v16i217226.

STRAZZI, S. Derivados do milho são usados PONTE, E. M.; DIONELLO, R. G. Qualidade físico-química de grãos de milho armazenados com diferentes umidades em ambientes hermético em mais de 150 diferentes produtos industriais. Revista Visão Agrícola, v. 9, n. 13, p. 146-150, 2015.

e não hermético. Revista Brasileira de Milho e Sorgo, v. 13, n. 2, p.174-186, 2014. DOI: 10.18512/1980-6477/rbms.v13n2p174-186.

SCHUH, G.; GOTTARDI, R.; FERRARI UNITED STATES DEPARTMENT OF FILHO, E.; GUIMARÃES, L. E.; DIONELlO, AGRICULTURE (USDA). Coarse grains: R. G. Efeitos de dois métodos de secagem sobre World Coarse Grain Trade. 2019. Available in: a qualidade físico-química de grãos de milho safrinha-RS, armazenados por 6 meses. Semina: Ciências Agrárias, v. 32, n. 1, p. 235-244, 2011. 2019.

TIBOLA, C. S.; FERNANDES, J. M. C.; GUARIENTI, E. M. Effect of cleaning, sorting and milling processes in wheat mycotoxin content. Food Control, v. 60, n. 1, p. 174-179, 2016. DOI: 10.1016/j.foodcont.2015.07.031. 